DOI 10.31718/2077-1096.21.2.195

УДК:378.147-054.6

Klypachenko I.V., Levkov A.A.

\title{
ADAPTATION AMONG FOREIGN STUDENTS IN UKRAINE
}

Ukrainian Medical Stomatological Academy, Poltava

The processes of globalization and internationalization are the main factors, which have made a great impact on the evolution of higher education in the last decades of the $21^{\text {st }}$ century. The number of foreign higher degree students in Ukraine has grown at a significant rate in recent years, with the country offering a high quality higher education and, as a result, becoming one of the main European hubs attracting students from all over the world. In the article, the term "foreign student" is referred to any student who goes to another country in pursuit of learning. Since the emergence and popularization of the recent trend of studying abroad, the topic of adaptation of foreign students has become of the key interest among modern European scholars who have become concerned with studying the peculiarities, issues and challenges of living and learning in an unfamiliar social, cultural, and academic environment. With no doubt, studying abroad delivers new knowledge, experiences, and opportunities. However, the adaptation to a host country and a new environment that is far away from home countries, families, and friends, sometimes takes a long time. Moreover, usually, it is challenged with several difficulties including lack of motivation, discouragement, depression, stress, anxiety, psychological conditions, culture shock, loneliness, misunderstands, conflicts, communicating with peers, language incapability, understanding lectures, learning new social norms, and interacting with people from different cultural backgrounds. As a result, these stressors have a great impact on foreign students' physical and psychological well-being and challenge their wish, motivation, opportunity and capability to participate fully in the process of the cultural and academic adaptation. Even if the universities and host society provide helpful sources and advantageous conditions to enhance the process of their adaptation, sharp differences in socio-communicative environments of the countries, as well as cultural and language differences pose several problems foreign students usually face influencing their present academic performance and future professional medical practices. In the article, the authors discuss the issues of the geographic, psychological, socio-cultural, and linguistic methods of adaptation that have an impact on foreign students' academic performance, social integration, and career. The authors represent the findings of several studies on the topic exploring characteristic features of the adaptation of students in the higher education institutions of Ukraine. The general purpose of the article is to examine the adaptation using a theory-based explanatory approach. In this study, the adaptation is discussed as part of the social responsibilities of the universities and foreign students. On the one hand, higher education institutions must provide the necessary services and activities to help foreign students to combat the stressors they face in the process of adapting to the Ukrainian socio-cultural and educational environment. Moreover, universities need to ensure equal rights and opportunities for students' participation in academic life, as well as apply the most effective methods of foreign language learning. On the other hand, foreign students must be motivated enough to take the advantage of the opportunities and resources provided by universities and be responsible for the success of their adaptation to the social and academic life of the host country.

Key words: globalization, foreign students, adaptation, academic performance, foreign language proficiency.

The importance of adaptation of foreign students into the culture and the system of education of a host country at times of rapid globalization and internationalization has been studied by several scholars in the 21st century [1,2,3,4,5]. Adaptation has an undeniable impact on the academic performance of students and their future professional medical practice. In the last decade, the processes of globalization and internationalization have influenced students' migration within the countries and made it easier to travel around the world for the education processes freely. This tendency gave the ride for the modern studies of the ways and methods universities should apply to provide unique environments for foreign individuals and prepare them to be motivated to grasp skills and to be able to acquire knowledge. However, it is a complicated issue as usually foreign students cannot escape the cultural shock and linguistic gap in a host country. They face challenges such as different learning styles, unfamiliar living conditions, differences related to a language, as well as cultural and personal barriers, which may have a significant impact on their psychological state, academic performance and professional practice [1].

As the number of foreign students travelling abroad for educational purposes increases as the result of rapid globalization and internationalization, universities require institutional and academic reactions to be evolved providing more resources of support to address the problems of adaptation of foreign students. Adaptation is one of the main elements of educational and social inclusion; that, in case of its failure, may lead to several consequences, including interpersonal conflicts, anxiety, discouragement, poor learning result, poor satisfaction with studies and future profession, and sense of social isolation [2]. There are three main methods of adaptation foreign students usually deal with, namely: geographic adaptation, psychological adaptation, and socio-cultural adaptation. Geographic adaptation means students' adaptation to the characteristics of a host country's locality and their familiarity with the place of residence and the educational institution. Psychological adaptation is foreign students' psychological reactions to changing surrounding conditions they face when migrating for

Том 21, Випуск 2 (74) 
educational purpose. To become social-culturally adapted foreign students need to be familiarized with the culture and traditions of a host country and be able to fit with them to interact with members of society. Socio-cultural adaptation is usually associated with culture learning and acquisition of social skills in the host culture, that may be influenced by various variables such as language ability, adaptation strategies, length of residence in a host culture, cultural distance, age, interactions between foreign students and host nationals, etc. Positive emotions in relationships with others, high self-esteem, pleasant educational environment, motivation, and sense of spiritual comfort are the keys to successful geographic, psychological and socio-cultural adaptation. Educational institutions should provide a complex program on the adaptation of foreign students to enhance their inclusion into the academic and social life of a host country that will help them to acquire appropriate knowledge and obtain professional qualifications [4].

The results of the academic courses largely depend on students' competence in the language of instruction that is usually provided in Ukrainian. According to Article 20 of the Law of Ukraine "On fundamentals of state language policies", a Ukrainian language is an official language that is used on the whole territory of the state in general, and in educational establishments in particular. There is an opportunity of choice of languages for instructions (for instance, English). However, it can be realized in case if learning Ukrainian as the official language is a compulsory subject and is done in the scope that is sufficient for integration into Ukrainian society [6]. While the Ukrainian language is the language of instruction and the language of the courses of most students in the universities; English has been introduced as the language that may be performed in the national higher medical schools in Ukraine since it is the worldwide official language in the world of science. This gives foreign students an opportunity not to be required to take preliminary courses and learn Ukrainian, but study in the English language. However, communication with patients and lecturers, and everyday communication cannot be carried out in English only because the majority of ordinary Ukrainian citizens either do not speak it or prefer to speak Ukrainian as the mother tongue. That is why, Ukrainian language proficiency as the host country language proficiency is one of the main factors that contribute to the successful adaptation and adjustment of foreign students, and is one of the main determinants of academic experience professional performance. The (in)ability to communicate in the host language influences socio-cultural and linguistic adaptation. Acquisition of the basic skills of reading, writing, and speaking of a host country's language additionally contributes to the personal and professional life of foreign students. Moreover, while learning a language of a country of residence, foreign students may acquire vital skills for communicative situations, skills for critical thinking, and skills for independent learning [7].
To enhance students' linguistic competence, educational institutions should develop linguistic and cultural work within the mandatory and special courses of the language departments. According to the European Parliament's Recommendations on Key Competences for Lifelong Learning, the competence in speaking a language of a host country includes knowledge of accepted norms, traditions, values and customs of society; ability to understand, process, express and interpret the concepts, thoughts, and feelings in an appropriate range of social and cultural contexts [8]. That is, linguistic competence is very important for foreign medical students since it may give them the necessary basis in mastering the academic knowledge and professional competence required to become a qualified medical specialist.

We consider it important to emphasize that the effects of foreign language acquisition depend largely on adequate contact with language: language becomes easier to learn when a person speaks it frequently. Moreover, language learning in a naturalistic communicative setting is driven by meaningful interaction and a sense of belonging. In comparison with local students who speak Ukrainian at home, in school, with friends; foreign students spend minimum time for speaking Ukrainian: a few hours at classes and a little time in everyday life. Therefore, teachers are also responsible to contribute into a successful adaptation of foreign students providing certain materials and strategies to enhance second language acquisition [10]. Moreover, the use of a mediator language (similarly to the language of instructions) in teaching a foreign language is important since with the help of it the lecturers can explain to students the peculiarities of language phenomena and processes [9].

In any type of adaptation, psychological, linguistic, or socio-cultural, the behaviour of foreign students may be described using the following components that influence success: motivation, adequacy, adaptability, authenticity, productivity, level of activity, initiative, self-control, etc. The main factors that may contribute to the successful adaptation of foreign students in the conditions of Ukrainian society and Ukrainian higher education institutions:

- Personally-motivational perspective on the higher education institutions and the process of study being motivated and willing to acquire academic competence.

- Acceptance and understanding of the educational information, tasks, and objectives in Ukrainian or English languages with further willingness to succeed in them.

- Overcoming the language barrier to comprehend information, learn the terms, understand instructions and assessment issues, provide an associative synthesis of the answer to the task, etc. in English or Ukrainian.

There is a need for the in-depth researches on foreign students' adaptation to the educational process in the national higher medical schools. The future studies on modern methods of teaching a foreign language as the language of instructions or 
the language of learning in a medical university, the impact of motivation in adaptation on academic performance, as well as the ways of the assistance of higher education institutions in their adaptation may contribute into the complex social and pedagogical topic of modern foreign students' adaptation.

\section{Література}

1. Ferencz V, Hrehova D, Senova A. Higher education require adaptation of students study abroad programs. SHS Web Conferences [Internet]. 2020 Jan; 74: 1-6. Available from: https://www.shs-

conferences.org/articles/shsconf/pdf/2020/02/shsconf glob2020 0 2003.pdf.

2. Biserova, GK, Shagivaleeva, GR. Socio-Psychological Adaptation of International Students to Learning and Professional Activities. Space and Culture in India [Internet]. 2019 Mar; 6(5): 99-114. Available from: https:// www.researchgate.net/ publication/332844123 Socio-Psychological Adaptation of International_Students_to_Learning_and_Professional_Activities. MacGregor, A, Folinazzo, G. Best Practices in Teaching International Students in Higher Education: Issues and Strategies [Internet]. TESOL Journal. 2018 June; 9(2): 299-329. Available from: https:// www.researchgate.net/ publication/318173978_Best_Practices_in_Teaching_International Students_in_Higher_Education_Issues_and_Strategies

4. Bondarchuk, L, Podgurska, T, Kovtunets, O. Intercultural Component in Teaching Foreign Students in Ukraine. Proceedings of the nent in Teaching Foreign Students in Ukraine. Proceedings of the
III International Scientific Congress Society of Ambient III International Scientific Congress Society of Ambient
Intelligence; 2020; Advances in Economics, Business and

\section{Реферат}

Management Research [Internet]. 2020; 129: 316-322. Available from: https://www.atlantis-press.com/proceedings/isc-sai20/125937243.

5. Edele, A, Schotte, K, Kempert, S. Does competent bilingualism entail advantages for the third language learning of immigrant students? Learning and Instruction [Internet]. 2016 July; 58: $332-$ $344 . \quad$ Available from: https://www.researchgate.net/publication/326658134_Does_comp etent_bilingualism_entail_advantages_for_the_third_Tanguage_lea rning_of_immigrant_students

6. Pro zasady derzhavnoyi movnoyi polityky" 2012 [Internet].[ On the principles of state language policy] Available from: principles of state language policy] Available from:
http://zakon3.rada.gov.ua/laws/show/en/5029-17. (Ukrainian). http://zakon3.rada.gov.ua/laws/show/en/5029-17. (Ukrainian).
Rudenko, N. Socio-cultural and psychological problems of foreign students adaptation in a higher school. Vestnyk KHADI [Internet] 2016; 73: 21-23. Available from: https:// dspace.khadi.kharkov.ua/ dspace/bitstream /123456789/1746/1/N_73_05.pdf.

8. Council Recommendation on Key Competences for Lifelong Learning. European Commission. Council Recommendation [Internet]; 2018. Available from: https://eur-lex.europa.eu/legalcontent/EN/TXT/?uri= uriserv:OJ.C .2018. 189.01 .0001$. 01.ENG\&toc=OJ:C:2018:189:TOC.

9. Nazarevych, LT, Denysiuk, NR, Havdyda, NI. Theoretical and practical approaches to teaching Ukrainian as a foreign language practical approaches to teaching Ukrainian as a foreign language at TNTU. Medychna Osvita [Internet]. 2020; 1: 56-61. Available
from: https:// ojs.tdmu.edu.ua/ index.php/ med osvita/article/ from: https:// ojs.tdmu.edu.ua/

10. Munoz, C. On how age affects foreign language learning. Advances in GALA. Research on Language Acquisition and Teaching: Selected Papers [Internet]. 2010; 39-49. Available from: https://www.enl.auth.gr/gala/14th/Papers/Invited\%20Speakers/Mu noz.pdf

\section{АДАПТАЦІЯ СЕРЕД ІНОЗЕМНИХ СТУДЕНТІВ В УКРАЇНІ}

Клипаченко І.В., Левков А.А.

Ключові слова: глобалізація, іноземні студенти, адаптація, навчальна успішність, володіння іноземною мовою.

Процеси глобалізації та інтернаціоналізації є одними із найголовніших факторів, що вплинули на еволюцію та розвиток сучасної вищої освіти у 21 столітті. Кількість іноземних студентів, що приїжджають до України з різних куточків світу з метою здобування медичної освіти у вищих навчальних закладах, значно зросла протягом останніх років. На сьогоднішній день країна пропонує якісну вищу освіту і $€$ одним із головних європейських центрів, що залучає студентів з усього світу. У статті під терміном "іноземний студент" розуміється будь-який студент, який приїжджає до іншої країни з метою навчання. “Адаптація" є процесом пристосування людини до умов навколишнього середовища. 3 моменту появи тенденції до навчання за кордоном, тема успішної адаптації іноземних студентів стала популярною серед сучасних європейських науковців, які вивчають особливості, функції та проблеми адаптації до життя та навчання в новому соціальному, культурному та навчальному середовищі. Без сумніву, навчання за кордоном дає нові знання, досвід та можливості. Однак найчастіше шлях адаптації іноземних студентів до нової країни є складним та довготривалим процесом, що потребує неабияких зусиль студентів та ресурсів університетів. Як правило, при цьому перед студентами виникають численні труднощі та перешкоди. Найбільшою проблемою являється туга за родиною та друзями, відсутність мотивації, депресія, стрес, переживання та тривога, культурний шок, самотність та небажання комунікації з оточуючими, недостатнє розуміння викладачів та системи освіти, конфлікти, спілкування з однолітками, незнання мови країни проживання, нерозуміння лекцій та завдань, вивчення нових соціальних норм та взаємодія з людьми іншої культури. Як результат, ці та інші стресові фрактори і проблеми мають великий вплив на фрізичне та психологічне здоров'я іноземних студентів. Вони перешкоджають їх бажанням, мотиваціям, можливостям та здатностям повноцінно адаптуватись до соціального та навчального середовищ. Дуже часто різкі відмінності в соціально-комунікативному середовищі країн, а також культурні та мовні відмінності негативно впливають на успішність іноземних студентів та рівень освіти і майбутньої професійної медичної практики. У статті автори обґрунтовують думку, що успішна географічна, психологічна, соціокультурна та мовна адаптація іноземних студентів $є$ комплексним процесом, який впиває на їх навчальну успішність, суспільну діяльність та професійний розвиток. Основним завданням праці $€$ аналіз різних наукових джерел та соціально-педагогічної літератури з метою визначення специфіки і особливостей різних методів адаптації до навчання іноземних студентів вищих медичних закладів України. У статті автори розглядають явище і процес адаптації у взаємодії соціальних обов'язків викладачів університетів та іноземних студентів. 3 одного боку, вищі навчальні заклади України повинні надавати необхідну допомогу іноземним студентам для боротьби зі стресовими факторами, з якими вони стикаються в процесі адаптації до українського соціокультурного та освітнього середовища. Викладачі вищих навчальних закладів також мають забезпечити рівні права, обов'язки та можливості для студентів у навчальному процесі, та застосовувати ефективні методи викладання іноземних мов. 3 іншого боку, іноземні студенти мають бути достатньо мотивованими, щоб використати можливості та ресурси, якими забезпечують медичні університети і бути відповідальними за успіх своєї адаптації до соціального та навчального академічного життя в іноземній країні. Автори

Том 21, Випуск 2 (74) 
наголошують, що однією з головних проблем адаптації іноземних студентів до життя і навчання в Україні є незнання української мови. Оскільки українська мова є однією з офріційних мов навчання у вищих учбових закладах та основною мовою професійної медичної практики на території України, рівень володіння нею впливає на навчальні, професійні та особисті аспекти життя іноземних студентів. Саме тому, однією із ключових тем статті $€$ тема успішної мовної адаптації студентів до навчального процесу у вищих медичних навчальних закладах. Автори презентують функції і специфіку мовної адаптації та наголошують про необхідність впровадження сучасних методів викладання іноземної мови, що сприятимуть вивченню української мови і підвищенню мотивації до адаптації до професійного і соціального життя.

\section{Рефрерат}

АДАПТАЦИЯ СРЕДИ ИНОСТРАННЫХ СТУДЕНТОВ В УКРАИНЕ

Клипаченко И.В., Левков А.А.

Ключевые слова: глобализация, иностранные студенты, адаптация, учебная успеваемость, владение иностранным языком.

Процессы глобализации и интернационализации являются одними из главных фракторов, повлиявших на эволюцию и развитие современного высшего образования в 21 веке. Количество иностранных студентов, приезжающих в Украину из разных уголков мира с целью получения медицинского образования в высших учебных заведениях значительно возросло в последние годы. На сегодняшний день страна предлагает качественное высшее образование и является одним из главных европейских центров, привлекает студентов со всего мира. В статье под термином "иностранный студент" понимается любой студент, который приезжает в другую страну с целью обучения. "Адаптация" является процессом приспособления человека к условиям окружающей среды. С момента появления тенденции к обучению за рубежом, тема успешной адаптации иностранных студентов стала популярной среди современных европейских ученых, изучающих особенности, функции и проблемы адаптации к жизни и учебе в новой социальной, культурной и учебной среде. Без сомнения, обучение за рубежом дает новые знания, опыт и возможности. Однако чаще всего путь адаптации иностранных студентов к новой стране является сложным и длительным процессом, требующим значительных усилий студентов и ресурсов университетов. Как правило, при этом перед студентами возникают многочисленные трудности и препятствия. Главной проблемой является тоска по семье и друзьями, отсутствие мотивации, депрессия, стресс, переживания и тревога, культурный шок, одиночество и нежелание коммуникации с окружающими, недостаточное понимание преподавателей и системы образования, конфликты, общение со сверстниками, незнание языка страны проживания, непонимание лекций и заданий, изучение новых социальных норм и взаимодействие с людьми другой культуры. Как результат, эти и другие стрессовые факторы и проблемы имеют большое влияние на физическое и психологическое здоровье иностранных студентов. Они препятствуют их желанию, мотивациям, возможностям и способностям полноценно адаптироваться к социальной и учебной среде. Очень часто резкие различия в социально-коммуникативном среде стран, а также культурные и языковые различия негативно влияют на успешность иностранных студентов, и уровень образования и будущей профессиональной медицинской практики. В статье авторы обосновывают мнение, что успешная географическая, психологическая, социокультурная и языковая адаптация иностранных студентов является комплексным процессом, который влияет на их учебную успеваемость, общественную деятельность и профессиональное развитие. Основной задачей работы является анализ различных научных источников и социально-педагогической литературы с целью определения специфики и особенностей различных методов адаптации к обучению иностранных студентов высших медицинских заведений Украины. В статье авторы рассматривают явление и процесс адаптации во взаимодействии социальных обязанностей преподавателей университетов и иностранных студентов. С одной стороны, высшие учебные заведения Украины должны оказывать необходимую помощь иностранным студентам для борьбы со стрессовыми фракторами, с которыми они сталкиваются в процессе адаптации к украинской социокультурной и образовательной среды. Преподаватели высших учебных заведений также должны обеспечить равные права, обязанности и возможности для студентов в учебном процессе, и применять эффективные методы преподавания иностранных языков. С другой стороны, иностранные студенты должны быть достаточно мотивированными, чтобы использовать возможности и ресурсы, которыми обеспечивают медицинские университеты и быть ответственными за успех своей адаптации к социальной и учебно-академической жизни в другой стране. Авторы отмечают, что одной из главных проблем адаптации иностранных студентов к жизни и учебе в Украине является незнание украинского языка. Поскольку украинский язык является одним из официальных языков обучения в высших учебных заведениях и основным языком профессиональной медицинской практики на территории Украины, уровень владения им влияет на учебные, профессиональные и личные стороны жизни иностранных студентов. Именно поэтому, одной из ключевых тем статьи тема успешной языковой адаптации студентов к учебному процессу в высших медицинских учебных заведениях. Авторы представляют функции и специфику языковой адаптации и отмечают о необходимости внедрения современных методов преподавания иностранного языка, способствующие изучению украинского языка и повышению мотивации к адаптации к профессиональной и социальной жизни. 